\title{
Where Are We Going? Perspective on Hindu-Muslim Relations in India
}

\author{
Sammyh S. Khan and Ragini Sen
}

The twin issues of making peace and building it over time, which are very much at the forefront of social concerns in contemporary India, remain a major source of worry and require a thoughtful understanding. The lack of effort that has been dedicated towards the development of a systematic understanding of the psychological dynamics underpinning intergroup hostility and violence between Hindus and Muslims in India is disappointing to say the least. While elaborate analyses and accounts of these intergroup dynamics have emerged from academic disciplines such as sociology, political science, economics and history (e.g. Basu, Datta, Sarkar, Sarkar, \& Sen, 1993; Brass, 2003; Engineer, 1995; Lal, 2003b; Ludden, 2005; Pandey, 1991; Varshney, 2002; Wilkinson, 2004), psychological theory and research with some predictive validity have been slow to emerge (Ghosh \& Kumar, 1991; Hutnik, 2004; Kakar, 1996; Nandy, 1990; Singh, 1989). This brings to the forefront a couple of basic queries: (a) how can the discipline of psychology contribute towards the current understanding of intergroup dynamics in India and (b) can psychological theory and research translate into knowledge and action to promote peaceful coexistence in applied contexts?

The objective of this chapter is to address these two questions which comprise the core of our account. We will begin this endeavour by briefly reviewing theoretical and empirical paradigms that have been explored previously. These will then be juxtaposed against the historical, social and political contexts of Hindu-Muslim relations in India to elucidate those issues that have been adequately investigated, but most importantly, those issues that need further elaboration and inquiry. Before embarking upon this assessment, we will provide a brief outline of the historical, political and social contexts of Hindu-Muslim relations in India. We maintain that for analysing socially meaningful phenomena it is necessary to depart from the habitually close confines of psychology's argumentation and to include historical, cultural, social and political perspectives in analysis and theorising (Valsiner, 2001). Consequently, this chapter aims to gather insights from other disciplines and integrate them with psychological understanding in order to help augment the psychology of peace and conflict resolution. 


\section{Hindu-Muslim Relations in Modern India: The Cultural, Historical, Political and Social Contexts}

Islam came into South Asia in the beginning as a religion and then as a political force. The Arab conquest of Sind (711-715) was followed later by raids into India by Mahmud of Ghazni (999-1026), rise of the principality of Ghor (1151-1192), Delhi Sultanate (1211-1504) and the Mughal Empire (1526-1858) at which point the last Mughal emperor was deposed by the British (Embree, A.T). Islam in India is the second-most practiced religion after Hinduism. There are approximately 151 million Muslims in India's population as of 2007 (according to government census 2001), that is $13.4 \%$ of the population. Currently, India has the third largest population of Muslims in the world. However, unofficial estimates, coming from both Hindu and Muslim sources, claim a far higher figure (20-30\%) supposedly discounted in censuses. This issue is prominent in political discourse and is amplified by representatives from both the communities. The pro-Hindutva forces claim that the high Muslim growth rate is intentional and a threat to the country and its Hindu character; Muslim spokesmen use it to raise the morale of a minority community perceived as under threat, economically as well as politically.

In pre-partition India, Mahatma Gandhi described the social tension between Hindus and Muslims as "the problem of problems" (1930, cited in Singh, 1989). This saw its manifestation at the time of the partition of the Indian subcontinent. The partition was witness to the large scale mass migration of 12-14 million people; killing of over one million; and sexual abuse of an estimated 100,000 women. This just constituted the core. All over India, millions were affected by Hindu versus Muslim riots which were incited by religious hatred and uncontrolled fury. This was the foundation and the reality of partition.

After partition there was an attempt to forget the painful past and as a corollary, a collective amnesia shrouded this traumatic period in India's history (e.g. Lal, 2003b; Pandey, 1991; Gooptu, 2002). Silence, denial and modification of memory were the defence mechanisms used to stabilise India and steer it towards a new era. In order to rectify this collective amnesia, social scientists are now trying to reconstruct the partition that had virtually become a taboo issue of research and collective thought. Prior to this, the available literature on partition recounts only its "high politics": the constitutional and political negotiations. The trauma and the tandava (dance of mass destruction) were forgotten. As far as historiography is concerned this fills an important lacuna. However, at the time of the partition, this imposition of collective amnesia or, as some would address it, "the tyranny of silence" was probably an astute political move. Brooding on this event and following the British policy of divide and rule would have further fragmented India, which it could least afford. The politics of memory was operationalised.

The nature of conflicts between Hindus and Muslims in India has undoubtedly changed since the partition. In independent India, all hues of ideological players have taken part in unleashing retributive violence. For instance, the Indian National Congress (INC) spearheaded the anti-Sikh violence of 1984, and traditionally the 
state governments led by the INC turned a blind eye to the violence perpetrated by Hindu communalists. The irony of it all is that Gujarat, the birthplace of Mohandas Karamchand Gandhi, in 1969, bore witness to a nasty bout of violence against the Muslims under Hitendra Desai, a "Gandhian". These were the bloodiest riots after 1947. It is important to bear in mind that the Hindu nationalist movement alone did not cause the rioting and massacres that occurred during the years of agitation leading up to the demolition of Babri Masjid (Akbar, 2003; Engineer, 1995). A long history of communalism (i.e. social tensions between ethnic communities) in which many sides joined over the decades preceded the demolition of the mosque. It would indeed be simplistic to reduce the history of communalism to the activity or ideology associated with any one set of sociocultural or political conglomeration because the history of Hindu-Muslim conflict in India is complex. However, overall, an interdisciplinary agreement exists that the increase of communal riots over the last three decades corresponds to the Hindu nationalist movement in India (e.g. Brass, 2003; Engineer, 1995; Jaffrelot, 1996; Ludden, 2003; Varshney, 2002; Wilkinson, 2006).

The term Hindutva (literally meaning "essence of Hinduism") was first coined and popularised by Vinayak Damodar Savarkar in his 1923 pamphlet entitled "Hindutva: Who is a Hindu?". Later it was identified with the Rashtriya Swayamsevak Sangh (RSS) and the Hindu Mahasabha, which stood for Hinduising India and militarising Hinduism (Ramakrishnan, 2007). The Muslim League was organised in 1906 to mobilise Muslim identities for increasing collective Muslim representation in British India (Hardy, 1972; Jalal, 1985). From the beginning, the RSS and allied organisations opposed efforts by Gandhi and the INC to unify Indians of all religions (Basu et al., 1993). All these political outfits had been driven by a strong religious ideology that had been euphemistically termed cultural nationalism. However, the most significant facts are as follows: India was born out of "partition", and Mohandas Karamchand Gandhi was shot by a Hindu. Nathuram Godse, incited by the Hindu lobby, while pretending to touch Gandhi's feet at a prayer meeting, fired at him because Godse believed that Gandhi was doing uncontrollable damage to the Hindu cause because of his "soft line" towards the Muslims. Gandhi paid with his life for his spirit of secularism and for his efforts at building bridges of peace.

Impelled by the disastrous consequences of ethnic conflict, which engulfed the subcontinent in 1947, the Indian government took on the role of reforming religion in the pursuit of social justice and equality. Hence, under the aegis of Jawaharlal Nehru (the first prime minister of independent India), the concept of secularism was imported from the West (Chopra, 1994). But its Western interpretation, which separates state politics from religion, was not followed.

Post-independence, although the constitution was secular, the state apparatus bureaucracy, judiciary, army and police - was infiltrated by Hindu communal elements. This resulted in a social development, which was mixed; on the one hand, secularism thrived, and on the other, communalism, which was hastily buried, did not die but remained dormant.

The contemporary Hindu nationalist movement is a network of organisations, with the core consisting of the RSS, an organisation which was launched in 1925 
on the Vijayadashami Day by Keshav Baliram Hedgewar to champion the cause of right-wing ideologues; the Bhartiya Janata Party (BJP) and the Vishwa Hindu Parishad (VHP). The movement has its roots in the Hindu Mahasabha, and the emerging new entity is collectively termed the Sangh Parivar - a family of organisations that promotes the ideology of "Hindutva."

Social changes during the late 1970s and early 1980s gave communalism a strong boost, bringing the Sangh Parivar into prominence, and this conglomerate started attacking secularism in a big way. The BJP took on the mantle of "the" communal party. It quickly mushroomed, introduced communal rhetoric in the social space and openly declared its agenda of Hindu Rashtra (Jhingran, 1995). It was quick to capitalise on decades of gradual permeation of Hindutva, and using this as a take-off point, launched an ideological, social and political onslaught on secular ethos (e.g. Basu, 1996; Bhargava, 2002; Brass, 1991; Jaffrelot, 1996; Kakar, 1996; Lal, 2003a, b; McGuire, Reeves, \& Brasted, 1996; Nandy, Trivedi, Mayaram, \& Yagnik, 1995; Pandey, 2001; Punyani, 2003; Varshney, 2002; Zakaria, 2002) and syncretic culture (Sen and Wagner, 2009).

Taking their lessons from this multilayered history, the BJP (1999-2004) made an attempt to orchestrate a social transition wherein an attempt was made to systematically crystallise ethnic identities. This trait is perceived in almost all kinds of nationalisms where, in the bid to create a nationalist identity, the immortality of the group is emphasised and the arguments in favour of its continuity underlined, so that people feel impelled to be the torch bearers (Smith, 1998). For instance, during the BJP regime, the push was that the core identity of a true Hindu be constructed around ancient Hindu lineage, acceptance of militancy, retributive justification of violence and perception of secular acts. Reviving Hinduism through the ancient Indian civilisation theme, the BJP was able to arouse the dormant embers of Hindu pride and retributive violence. Consequently, when the BJP and its allies sounded the clarion call for Hindu militancy, many jumped on the wagon. The BJP put into practice the processes through which traditions and past experiences are used to justify political agendas (Pennebaker, Paez, \& Rime, 1997; Reicher \& Hopkins, 2001; Sen \& Wagner, 2005). Events which followed showed that the agenda of balancing the acts of history was wilfully accepted. Through the agency of Hindu revivalism, an attempt was made to harness the Muslim community and thereby rectify the wrongs suffered by the Hindus when they were under the domination of the Muslims. The project of Hindutva, which basically focuses on the building up of a mass mobilisation geared to the task of forging a new "Hindu" nation, began to take shape, and new symbols were created to operationalise this agenda.

Events which have been witnessed throughout the last decade until the present establish that Babri Masjid had been the strongest political and social mobilising force of the Hindutva ideology. The controversial issue of the birthplace of Lord Rama (Babri Masjid-Ram Janambhoomi) has a long past. It started in 1855. The Babri Masjid is a mosque in Ayodhya, which is situated in the state of Uttar Pradesh in northern India. It was built by Mir Baqi, a nobleman in Babur's court, in memory of the emperor Zahiruddin Muhammad Babur Badshah Ghazi, a minor prince of Ferghana (in modern-day Afghanistan) who founded the Mughal Empire in India, 
which ruled until the British $R a j$ finally replaced it after the general mutiny of 1857 failed.

On the night of 22 December 1949, idols of Lord Ram were installed in the mosque. This started the controversy that came to the fore in 1984 when the first "religious parliament" (Dharma Sansad) of the Vishwa Hindu Parishad (VHP, World Hindu Council) decided to "liberate" the site of Ram's birth (janam).

Campaigning for the "liberation" of the birthplace and temple of Lord Rama in the late 1980s, L. K. Advani, the home minister of the BJP, embarked on a chariot march (Rath Yatra) that was reminiscent of Hindu epics such as Ramayana and Mahabharata. He started the journey from the Somnath temple in Gujarat and continued for weeks before the crusade was stopped in Bihar where L. K. Advani was arrested (Sen \& Wagner, 2005). Although the nature of the campaign was peaceful, 300 communal riots, the largest number since partition, erupted across India in the same year (Shah, 2004). Markedly, the BJP also gained increased political support.

Following this, a clarion call was made for volunteers (kar sevaks) to assemble at Ayodhya on 6 December 1992. Millions of volunteers, from all over India, assembled, and in the ensuing fray, the Babri Masjid was demolished in five and half hours of frenetic activity and its debris thrown in the river Sarayu. Shortly after the demolition, massive riots took place all over India and with a demonic ruthlessness. The BJP entered the fray and made political capital of the situation.

In 1989, the BJP held only two out of the 544 seats in the Lok Sabha (Lower House). By 1998, the party had gained 182 seats and ran the government of India until 2004. Undoubtedly, Babri Masjid, which in reality was a structurally dilapidated monument, was the core image around which the entire edifice of Hindutva was created. The core image of Babri Masjid - or figurative core (Moscovici, 1976; Abric, 1996) - determined each element of right-wing fundamentalism, its presence, its value and its function. Connecting an event in political discourse with Babri Masjid, it seems, was a guarantee to attach symbolic meaning to it, and vice versa, mentioning the event in turn appeared to objectify the symbol of Babri Masjid in the national identity. Thus, the trinity of Babri Masjid, Ayodhya and Lord Ram reaped rich dividends for the BJP and brought it to centre stage.

The power of such events to spark widespread violence and consolidate Hindutva was demonstrated again a decade later, when a massacre in a train in Godhra (in the state of Gujarat) left 37 Hindu voluntary workers dead. The workers had been returning from a ceremony in Ayodhya and were burnt to death. The tragedy was blamed on Muslim "terrorists" and triggered violent riots of unparalleled brutality. Hindu mobs targeted Muslim communities throughout the state, and it was reported that members of the RSS and VHP led the riots. Human rights groups estimated that the death toll reached between 2,000 and 2,500, with a further 140,000 people dislocated in the aftermath of the massacres, many of whom still remain homeless (Brass, 2003; Shah, 2004). In this telling, if not a shocking example of identity politics, leaders of the BJP and VHP converted the train massacre into a symbolic representation that mobilised mass support for Hindutva, while the riots became symbolic of Hindu victory over Muslim oppression. 
Godhra succeeded in keeping the Babri symbol alive and consolidated Hindutva. These religion-inspired perceptions thus cast their shadows on everyday situations and were mapped onto the symbol, the masjid, as metaphorical entailment (Lakoff, 1987). Thus, memories related with the event in the past (Babri Masjid, Ayodhya) became associated with the new representational image (Godhra) and fuelled cognition and affect. This new representation had the power to vitiate institutional politics. It appears that the evocative strength of these representations, Godhra and Babri Masjid, when associated with dominance of Hindus, helped to anchor Hindutva, which symbolically represented itself as the supreme saviour of the threatened Hindu dharma (religion).

\section{Trends in Psychological Research}

Unfortunately, the complex and multilayered cultural, historical, political and social contexts of Hindu-Muslim relations in modern India described above have not been mirrored in the psychological literature. A summary of the existing body of psychological theory and research addressing Hindu-Muslim relations paints the picture of a fundamentally fragmented and limited literature. Psychologists across the disciplinary spectrum have continuously failed to adequately place mainstream theories and methodologies within the contextual complexity of Hindu-Muslim relations. Limited samples, measurements and statistical tests have been ubiquitous. University students, adjective checklists, t-tests and correlations have hardly been compelling in explaining deeply entrenched intergroup dynamics. These points are still minor compared to the questionability of mainstream intergroup perspectives and their relevance for assessing and understanding the complex processes within which Hindu-Muslim relations in India are embedded. Theory building and research simply cannot attain any predictive validity if the historical, political and social contexts are ignored. In this part of the chapter, we illustrate the discrepancy between the psychological literature and the context of Hindu-Muslim relations in India.

As a brief note, we would like to acknowledge that the existing body of psychological literature investigating Hindu-Muslim relations in India has been reviewed in different outlets, at different points of time (e.g. Ghosh \& Kumar, 1991; Hutnik, 2004; Singh, 1989), and that this chapter does not set out to recreate these accounts. Although they have been used in outlining this section, we have structured it differently by presenting and adding research with the intention of assessing the literature from a peace psychological perspective.

\section{Early Trends and Mainstream Developments}

The first, but probably most overlooked, psychological inquiry into Hindu-Muslim relations in India was conducted by K. M. Panikkar and published in The Contemporary Review in 1927. The paper entitled The Psychology of the Hindu-Muslim Riots 
was written to address a marked increase in hostility and violence between Hindu and Muslim communities in pre-independent India. Refuting popular hypotheses about essentialist differences, Panikkar proposed that the increase in tensions between the two religious communities was a direct result of political rivalry and the distrust of motives in the process of democratisation in India. While the Hindu community believed that every Muslim worked secretly for the establishment of Muslim power in India, there was a conviction among the Muslim community that Hindus wanted to expel them from India. Regardless of the "primitive and barbarous" (p. 235) nature of the Hindu-Muslim riots, Panikkar argued that they were an indication of Indian dynamism striving to establish a relational definition upon which a healthy national life could later be structured.

Another landmark study was conducted by S. P. Adinarayan and was part of his systematic research programme assessing colour prejudice $(1941,1964)$ and racial and communal attitudes $(1953,1957)$. The paper entitled Before and After Independence: A Study of Racial and Communal Attitudes was published in The British Journal of Psychology in 1953. The paper reports results from a longitudinal between-subjects study of Hindu versus Muslim students and professionals' attitudes towards a range of nationalities, such as Americans, Chinese and Turks, in two samples collected before (1934-1945) and after (1950) the partition. Most importantly, the study examined Hindu and Muslim participants' attitudes towards each other's religious communities. The results showed that both Hindu and Muslim professionals rated the outgroup more positively than students before the partition. Data was collected only among Hindus after the partition and revealed that they rated Muslims more negatively compared to what they had done before the partition.

Panikkar's (1927) and Adinarayan's (1953) papers deserve mentioning because of the pre- and post-independence contexts in which they were published, but their influence on subsequent Hindu-Muslim relations are not comparable to that of Gardner Murphy's (1953) book, In the Minds of Men: The Study of Human Behaviour and Social Tensions in India. The book summarises three years of research commissioned to UNESCO by the Indian government in 1949 to examine the nature of communal tensions in post-independence India, but also to advise the government on policies for the promotion of social harmony. Multidisciplinary teams of Indian academics were organised and devoted to examining intergroup issues of key concern in post-independence India. These issues included the following: (a) the hostility between Hindu residents, Hindu refugees and Muslim residents in Bombay; (b) Hindu-Muslim relations in Bombay, Lucknow and Aligarh; (c) the adjustment of refugees from East Pakistan (now Bangladesh); (d) the attitudes of textile mill workers in Ahmedabad and (e) Hindu and Muslim attitudes towards the tribal population of India. All of the studies were conducted through interviews and the administration of attitude questionnaires. The book presents a general description and rationalisation of the research, but does not report the research in full. The reported findings are too dense to review here, but to provide a gist, excerpts from the first study described how the Hindu refugees reported bitterness and frustration about their dependence upon the government and their lack of access 
to economic resources and geographic space, whereas the Muslim residents of Bombay reported uncertainty in their request for equal-citizen status. On the other hand, the Hindu residents of Bombay reported being very much uninformed of the problems of either the Hindu refugees or the Muslim refugees. Gardner (1953) sourced social tensions in Bombay to the lack of inter-communication between the two groups.

\section{Contributions Central to Intergroup Research}

While Gardner's (1953) undertaking was central in stimulating the development of intergroup research in India, Sinha (1998) and Pandey and Singh (2005) recognised that the fruitful foundation laid by Gardner had been lost over time. Subsequent intergroup research degenerated into causal investigations of the relationships between demographics and personality variables with caste, religious and other forms of prejudice. This critique still remains relevant and has been supported in other reviews of the Hindu-Muslim intergroup literature (e.g. Ghosh \& Kumar, 1991; Hutnik, 2004; Singh, 1989). An overview of this substantial body of research is outside the purview of this chapter; hence, we will limit our observations to a few highly cited and influential papers.

Taylor and Jaggi's (1974) classic study of stereotypes and intergroup attributions in South India is by far the most cited publication. Their materials included 16 scenarios, involving a Hindu or Muslim actor behaving in either a socially desirable or undesirable way. Four or five possible explanations reflecting internal and external attributions of the behaviours were given per scenario. Two identical adjective checklists of positive and negative traits pertaining to Hindus and Muslims were also included in the survey. Without any reference to the history or the state of HinduMuslim relations in India at the time the research was conducted, their results showed that intergroup attributions and trait ratings were both ingroup favouring and outgroup derogating. Taylor and Jaggi suggested that their results had confirmed the link between attitudes, attributions and behaviour by simply having compared intergroup attributions side by side with corresponding patterns of trait ratings, rather than having examined their empirical connection. Although conducted in India, this study has been referenced more widely within mainstream social psychology and was one of the key pieces of empirical evidence presented in the formulation of Pettigrew's (1979) "Ultimate Attribution Error."

The second most cited and arguably influential paper is Tripathi and Srivastava's (1981) study of relative deprivation and intergroup attitudes among Muslimuniversity students. Their materials consisted of a scale measuring relative deprivation across economic, political and social domains and two identical adjective checklists of positive and negative traits that assessed perceptions of Muslims and Hindus in India. Median splits and t-tests of the responses showed that Muslim participants with high, compared to low, levels of relative deprivation displayed more ethnocentric attitudes towards Hindus. 
Finally, the third most cited paper is Hassan and Khalique's (1981) study of religiosity and its correlates. Muslim participants were found to be more religious than the Hindu participants, and religiosity was correlated positively with anxiety, authoritarianism, intolerance for ambiguity and rigidity among both groups. Separate correlations for members of the two religious communities were not presented. Caste, gender, urban and rural differences were also compared, but showed no differences in scores between the Hindu and Muslims participants. The higher levels of religiosity found among the Muslim participants attributed the Muslim community's minority status and subjective feelings of insecurity and anxiety created by frequent communal riots.

The three studies outlined above provide a fairly objective representation of the quality of intergroup research undertaken in India and the areas covered. Unfortunately, recent research trends have generally not been more innovative, nor have they expanded in scope or enhanced in sophistication (e.g. Bano \& Mishra, 2005; Basu, Hasan, Gangjee, Dasgupta, \& Dey, 2005; Basu, Kaur, Ahluwalia, \& Gangjee, 2006; Gaur, 2004; Mishra, 2005). There have been exceptions; however, even these have failed to contextualise the dynamics between the two religious communities. Theoretically and methodologically rigorous studies examining Norm Violation Theory (Ghosh, Kumar, \& Tripathi, 1992), the Ultimate Attribution Error (Khan \& Liu, 2008) and Integrated Threat Theory (Tausch, Hewstone, \& Roy, in press) among Hindus and Muslims in India have all involved the blind implementation of mainstream theories of intergroup relations. The only contextual factor that has really been taken into account is the relative demographic size and status of the two religious communities in India, that is the Hindu community's majority status and the Muslim community's minority status. Community-level differences and unanticipated results have been attributed to a wider range of historical and sociopolitical factors by default, but these have never been operationalised, empirically tested or explained.

\section{A Peace Psychological Perspective of Hindu-Muslim Research}

Peace psychologists (e.g. Christie, 2006; Leong, 2003; Montiel, 2003; Vollhardt \& Bilali, 2008) and Indian social psychologists (e.g. Ghosh \& Kumar, 1991; Hutnik, 2004; Pandey \& Singh, 2005; Sinha, 1998) agree that research and theories emanating from their respective, yet overlapping, disciplinary domains of inquiry cannot ignore the wider contexts of the people and processes that they set out to understand. Sinha (1998) and Pandey and Singh (2005) have taken this standpoint towards the Indian literature in general and propagated for increased cultural relevance through the indigenisation of theory and methodology. Ghosh and Kumar (1991) and Hutnik (2004) addressed the Indian Hindu-Muslim literature specifically and were in general agreement with peace psychologists (e.g. Christie, 2006; Leung, 2003; Montiel, 2003; Vollhardt \& Bilali, 2008) regarding the importance of contextualisation in studying the antecedents of intergroup 
violence and harmony. There is no doubt that these calls for contextualisation are important, but they run the risk of lingering in the same vacuum as the existing body of Hindu-Muslim literature, without complementary suggestions for improvement.

Even if miniscule, there has been an alternative line of Hindu-Muslim research surfacing in the peripheries of mainstream social psychology. Moving beyond the study of mental processes, the primary focus of this trend has been the study of historical, cultural, social and political contexts within which the Hindu and Muslim communities of India are embedded.

At this point it is appropriate to dip into history. As described at the outset of this chapter, the most significant change in Indian society in the last two decades has been the switch in the political hegemony of the INC and their secular democratic politics to the establishment and legitimisation of chauvinistic and exclusionary Hindu nationalist ideologies across the spheres of Indian society. Social psychological literature in this field has dealt with these issues in greater depth than was usually seen in earlier studies which, having been tied by the constraints of psychology per se, remained microscopic in their approach. The following research studies have perhaps transcended this limitation, and we will briefly describe them since they may help create a trend towards a more robust understanding of psychological issues related to conflict, violence and, by default, peace and conflict resolution.

Tripathi (2005), in his paper on Hindu Social Identities and Imagined Past: The Face-off Between Ram Temple and Martyred Mosque at Ayodhya, succinctly argues that social identities emerge and fade on the basis of a social context, and most often situations are attributed meanings which are based on one's lived experiences. In the course of the paper, Tripathi assimilates the discourse on communalism and its various hues to help understand the dynamics of the Ram Janambhoomi issue at Ayodhya. The historical context of the conflict is presented and an attempt is made to demonstrate how past memories are selectively employed for the dual purpose of constructing as well as maintaining social identities. This thesis has been supported by interview data obtained from both Ram Bhakts (devotees of Ram) and students. It is illustrated that the formation of social identities is a complex and continuous process in which groups use different pasts. The final argument is that in contemporary India, there is a need to create a space for positive recollection of the past and to integrate it with the present in order to help create a syncretic culture.

Similarly, making use of interview data, Sen and Wagner (2005; 2009; Sen, 2005), with the belief that Hindu-Muslim conflict in India poses a permanent threat to the country's peace and civil relations, conducted a field study in Dharavi, allegedly Asia's largest slum and high on the scale of a riot-prone area. The respondents belonging to both Hindu and Muslim communities were personally familiar with violence since they resided in Dharavi, where the demolition of the mosque at Ayodhya had been the site of one of the bloodiest riots. Given the communal surcharge and politically sensitive nature of the research, they made use of visual stimuli. In order to illuminate the symbolic representational value and 
affective power of pictorial propaganda, images depicting historical events (such as those from the 1992 and 2002 events, as well as from earlier events) and political symbols were presented to Muslim and Hindu respondents in an interview. The respondents were shown the visuals and then their reactions, which became akin to storytelling, were probed. Reference can be made to Mamali (2006), regarding the usefulness of this methodology and its implications. Setting aside interviewrelated logistics, visual stimuli were also used by Sen and Wagner because they believed that historical symbols are part of a cultural narrative which can be used to mobilise public opinion, since it is assumed that there is a feedback loop between representations of the past and the social identities of the here and now.

In their first paper, Sen and Wagner (2005) show how symbols used in daily political life are powerful in evoking representations from past events, for example relating to the division of India more than half a century ago. They argue that these representations are still strongly affectively charged and lend their mobilising force to promote interethnic hatred and violence even today, and accordingly are exploited by fundamentalist politicians. Hindu and Muslim representations are similar in their cognitive content, but opposed in their affective and motivational charge.

Based on the same field study, Sen (2005) in Us vs. Them and Gandhi: The Case of Hindu-Muslim Conflict in India argues that symbols, myths and metaphors (social representations) can modify the existing knowledge base. Their results showed that by changing the definition of words and by the introduction of a new representation, Hindu nationalist ideologues made an attempt to change collective thought and thereby increase their hold on the Indian mindset, and Militant Hinduism, a new reincarnation of Hinduism, had slowly become a shared representation. Members of both Muslim and Hindu communities had begun to feel that their religious identity had been diluted and that this should be rectified. Thus, social positions and newly emerging social identities had begun to anchor and force themselves upon the cognitive system.

Adding yet another dimension to the research on Hindu-Muslim relations, Sen and Wagner (2009), in Cultural Mechanics of Fundamentalism: Religion as Ideology, Divided Identities and Violence in Post-Gandhi India, analyse the history and present of Hindu fundamentalism as it developed since India's independence. It is shown that in the course of its rise, Hindutva deconstructed Gandhian symbolism of non-violence, re-interpreted cultural symbols to become political signs and prepared the ground for communal violence. Secularists and the religious outgroup Muslims - became targeted as enemies. In the resulting Hindu ethnic dominance, religion was changed from being a faith and turned into an ideology. It is shown that such an ideologically charged mindset draws on a distinct religious and ethnic identity, erects strict borders towards other groups and justifies violence against them by their mere otherness.

A different methodological approach to the same phenomena has been taken by Khan, Liu and Fischer $(2007,2008)$ in their ongoing research programme, which investigates the structure and content of the Hindutva ideology and its workings within India's social and political processes. Elaborate thematic analyses (Braun \& 
Clarke, 2006) of foundational and official Sangh Parivar publications, such as Savarkar's (1923) pamphlet Hindutva: Who is a Hindu? and Madhav Sadashiv Golwalkar (1939) book We or Our Nationhood Defined, yielded 10 recurring historical narrative templates (Wertsch, 2002) not only on the subjects of the heritage of the Hindu faith, people and nation, but also on the historical influences of Christianity and Islam in the Indian subcontinent. For example, one of the themes involves the idea that "true" Indians share a bond of common Hindu blood inherited from the ancient Indus civilisation. "Outsiders," such as Arabs, Turks and British, who cannot trace their heritage back to the Indus civilisation can therefore never consider themselves to be true Indians. A second theme involves the notion that India and Hinduism are indistinguishable. This ideological proposition actively rejects secular democratic governance of India and justifies the subordination of minority groups that are not indigenous to the Indian subcontinent, such as Muslims and Christians. Scale items were extracted on the basis of the thematic analyses in the second phase of the project and piloted together with a range of generalised psychological variables of prejudice. The quantitative analyses culminated in a 12-item scale of Hindutva ideology that predicted variance in socio-politically relevant dependent variables, such as support and justification for the demolition of the Babri Masjid and the banning of religious conversion of Hindus, above and beyond variables, such as Right-Wing Authoritarianism (RWA; Altemeyer, 1996) and Social Dominance Orientation (SDO; Pratto, Sidanius, Stallworth, \& Malle, 1994). The project is currently in its third phase, investigating how the relationship between Hindutva and prejudice towards Muslims is aggravated and mitigated by social processes, such as collective remembering (e.g. Middleton \& Edwards, 1990; Pandey, 2001), economic competition (e.g. Esses, Jackson, \& Armstrong, 1998) and intergroup contact (e.g. Allport, 1954; Hewstone \& Brown, 1986; Pettigrew, 1986).

The studies outlined above provide a convincing account of how a social phenomenon, comprehensively researched within the disciplines of history, political science and sociology (e.g. Brass, 2005; Engineer, 1995; Jaffrelot, 1996; Ludden, 2003; Varshney, 2002; Wilkinson, 2006), can and has been integrated into the domain of psychology. The research has described the sociopolitical context within which the indigenous Hindutva ideology emerged, qualitatively and quantitatively operationalised the ideology and examined the social and political processes within which the ideology is embedded. The research may be classified under indigenous and peace psychology. It contributes to both, but most importantly, it has contributed to an increased psychological understanding of one of the most pertinent sociopolitical dimensions within which the Hindu-Muslim relation in modern India is located.

Further, the cultural dynamics analysed in the above-mentioned studies cast some doubt on the view that religious fundamentalism is first and foremost a psychological phenomenon (Ellens, 2006; Hood, Hill, \& Williamson, 2005). We do not wish to minimise the role of psychological factors in general, but movements such as Hindutva as well as others around the world embrace too many different people to be accounted for solely by shared psychological traits; instead, the actors share a similar background of culture, social class and caste. Perhaps we may suggest that 
fundamentalist movements that blossom hand in hand with nationalist politics are at their core, collective events that irresistibly engulf the individual actors and bring them to commit acts that only become possible with the background of mass action. The underlying psychology is a societal psychology of collective representing and acting rather than a psychology of personality. We are talking here of collective states and not of individual traits.

An integration of indigenous and peace psychological perspectives will be fruitful not only in the development of a multidisciplinary study of Hindu-Muslim relations in India, but also in understanding intergroup relations in other parts of the world. Peace psychology explicitly recommends theoreticians and researchers to take into account the geo-historical context (Christie, 2006) in the study of intergroup violence and peace. Hence, it is directly aimed at building an understanding of the factors and processes that bring upon and reduce intergroup violence. Like indigenous psychology (e.g. Enriquez, 1994; Hwang, 2005; Sinha, 1998), peace psychology can be understood as the study of people for the people, with a focus on intergroup relations. The theoretical foundations of indigenous and peace psychology have already been paved, but the combination and application of these perspectives to the study of Hindu-Muslim relations in particular, and intergroup relations in general, remain unexplored. An indigenous approach to theory building and research would limit itself to the study of indigenous Indian constructs and processes, but combined with a contextualised peace psychological analysis of intergroup violence and peace, the scope can be extended to include complex multidisciplinary descriptions.

\section{Suggestions for Future Research}

No specific research programme can explain the complete spectrum of variables and processes underpinning any given intergroup context. A comparison of the literature that has emerged from psychology with the disciplines of history, political science and sociology suggest that multiple avenues can and should be further explored for the development of a peace psychology of Hindu-Muslim relations in India. Some frameworks that have emerged from other social sciences, which we believe warrant further psychological inquiry, will be proposed and outlined in this part of the chapter. Our suggestions are by no means complete, but provide some insights and examples of how interdisciplinary bridges can be built between psychology and other social sciences.

\section{Interethnic Engagement}

Varshney (2002), Brass (2003) and Wilkinson (2004) have proposed that HinduMuslim violence is likely to be instrumentally incited for electoral advantages, particularly in times of upcoming elections. For example, Hindu nationalist parties tend 
to represent primarily the upper castes and fail to attract lower-caste Hindus with promises of redistribution for two reasons. First, the promise would not be credible. Second, it may alienate upper-caste supporters. When electoral forecasts predict a loss or close race, Hindu-Muslim riots are incited to pull more support and votes from lower-caste Hindus for Hindu nationalist parties. Brass (2005) has referred to this as institutionalised riot systems.

But not all Indian cities experience outbreaks of violence in these times. Varshney (2002) has proposed that the main differences between Indian cities that experience Hindu-Muslim violence compared to peaceful coexistence are the levels of interethnic engagement experienced between the two religious communities. Interethnic networks build bridges, manage tensions and are agents of peace, but if the communities are organised along interethnic lines and the interconnections with the other community are weak, or even nonexistent, then eruptions of violence are likely. Varshney supported his thesis by classifying Indian cities into riot-prone versus peaceful cities on the basis of Hindu-Muslim riot statistics ranging from 1950 to 1995. Case studies of selected cities chosen on the basis of similarities in demographic proportions provided descriptions of how interethnic networks had failed to develop in riot-prone cities (e.g. Ahmadabad, Aligarh and Calcutta) and prospered in peaceful cities (e.g. Lucknow, Hyderabad and Surat). Everyday and associational engagement between members of the Hindu and Muslim communities in the form of routine everyday interactions, peace committees and business associations flourished in peaceful cities, whereas interethnic networks were weak and even nonexistent in riot-prone cities.

The role of interethnic engagement in the promotion of peace has arguably already been explored in studies of the contact hypothesis, but existing research has not told the complete story. Tausch et al.'s (2009) research examined intergroup contact without classifying the contexts within which the interactions were taking place. Furthermore, the research did not compare riot-prone versus peaceful cities. It is undoubtedly important to understand that intergroup contact affects intergroup attitudes, but to be able to translate research findings into preventions and interventions, it is even more important to understand the contexts within which intergroup contact promotes peaceful coexistence. How then do the contexts of Hindu-Muslim contact differ in riot-prone versus peaceful cities? What contexts of intergroup contact make the Hindu and Muslim communities more resistant to the pressures of polarising political discourses? Arguably, these two questions can be answered by examining intergroup contact in multiple contexts to explore the circumstances and conditions that most effectively buffer communal tension, prejudice and hostility. Adequate sampling from riot-prone and peaceful cities would allow for a comparison of differences in the nature of Hindu-Muslim contact in the two types of cities. The outcomes from such a research programme would systematically elucidate the psychological and structural variables that differ between the two types of cities. The research findings could then be used as an empirical foundation for lobbying social and political policies that promote peace in riot-prone cities. 


\section{Urban Versus Rural India}

Hindu-Muslim violence is primarily an urban phenomenon, and intergroup relations in rural India, where a majority of Indians still live, have largely been unaffected by outbreaks in the urban centres. Between 1950 and 1995, rural India accounted for just 3.6\% of the deaths in Hindu-Muslim violence (Varshney, 2002). Thus, there is a call for research to expand sample coverage into the rural areas of India, particularly in states fraught with communal tension and violence. Shankar and Gerstein's (2007) qualitative research provides one example of how the foundation of such research could be structured. Following the 2002 Gujarat riots, they interviewed a small sample of Hindu and Muslim residents living in the city of Vadodara and tried to describe the rationale for their perception of violence and their beliefs about solutions between the two religious communities. The interviews revealed that the residents had not experienced any particular change in the relationship between the two groups before and after the riots. There was always a sense of uncertainty and fear of another eruption, but generally the residents expressed hope for the future and for the younger generations to learn how to live in peaceful coexistence. The perpetrators were unanimously believed to be outsiders, and the responsibility for bringing peace and harmony was mainly perceived to be with the community itself, but also with the government. By asking larger samples of urban and rural populations similar questions, systematic comparisons of responses could unearth important differences in cognitions and processes underpinning communal tensions and peaceful coexistence between these two populations. Specifically, comparisons could clarify how intergroup perceptions and communications between the two populations differ in everyday interactions and during episodes of communal tension and violence. Elaborated insight into the difference between the two populations and how they cope with inflammatory political discourses would be particularly important and relevant. The findings could be used as an empirical foundation for future research addressing whether and how dynamics in rural communities can be implemented in urban populations to promote peaceful coexistence. Once a range of central factors and processes have been identified and narrowed down, research in this area would not have to be restricted to exploratory qualitative methods, but could also include quantitative methods and action research projects.

\section{Development and Operationalisation of Context-Sensitive Measures}

More importance has to be placed upon the development and operationalisation of context-sensitive measures in the future. For example, even though resistance against polarising political discourses could easily be assessed with scales of symbolic and realistic threats (Stephan \& Stephan, 2000), or with the Hindutva scale developed by Khan et al. (2007, 2008), existing scales of realistic and symbolic threats have not been developed, or even modified, for the Hindu-Muslim context. 
This is likely to explain why Tausch et al. (2009) did not find symbolic or realistic threats to mediate between intergroup contact and attitudes among either Hindus or Muslims. A more context- and conflict-specific modification of the scale items would very likely have yielded different results. For example, realistic threats commonly evoked by Hindu nationalist parties and politicians against Muslims include government funding for the maintenance of medieval mosques, the construction of new mosques, hajj subsidies and the inclusion of Muslims in the reservation quota for central government jobs and university admissions. Symbolic threats include conflicting loyalties and interests towards India and Pakistan among Indian Muslims and the fertility rate of the Muslim population, which is often argued to be proportionately higher than that of the Hindu population (see Jefferey \& Jefferey, 2002). These are just some examples of political content that could be integrated into the items of the existing scales of realistic and symbolic threats. The mediating effects of polarising political discourses could alternatively be manipulated in experimental settings by presenting Hindu and Muslim subjects with literary or audiovisual materials from actual political campaigns. Studies of this nature do not necessarily have to be limited to examining intergroup contact, attitudes and their mediators, but can also include a range of other relevant structural, social and personality variables. What is most important is that theories and methodologies that are implemented are grounded in the geo-historical context of HinduMuslim relations in India. This does not necessarily imply that frameworks derived from Western or other non-Indian contexts should be completely discarded; they just have to be adequately assessed and modified before implementation. Selected mainstream intergroup frameworks currently exist, for example intergroup emotions (e.g. Mackie \& Smith, 2002) and intergroup forgiveness (Moeschberger, Dixon, Niens, \& Cairns, 2005; Tam, et al., 2008, 2007; Philpot \& Hornsey, 2008), that certainly could prove to be relevant for the promotion of peaceful coexistence. Future studies could unveil not only how narrative templates of historical intergroup transgressions within the Hindutva ideology implicate adverse intergroup emotions, but also if and how these could be reduced by intergroup forgiveness. If the null hypothesis is rejected, the concept of intergroup forgiveness would warrant serious consideration in future research and roundtable discussions on policies for the promotion of peaceful coexistence between the Hindu and Muslim communities of India.

\section{Towards Syncretic Cultures}

In the aftermath of the Cold War, it is increasingly evident that violence is not primarily between nation states engaged in power plays; it is increasingly between ethnic or religious groups, often within nation states. The case of Hindu-Muslim conflict with which we have dealt is a pointer in that direction.

The communal environment that consequently loomed after the partition led Hindus and Muslims to anchor their sense of identity and self-esteem within their own 
cultural group. This enhanced a sense of security, but also pride that was stoked by demagoguery to help sustain their political agendas. This in turn strengthened each group's sense of identity, and not only promoted a negative perception of the other group but also led to a hetero-referential perception of experiences (Shankar \& Gerstein, 2007; Sen \& Wagner, 2005, 2009; Sen, 2005; Kakar, 1996, 2000). Ethnic identities became focussed, stereotypes heightened and a perception of each other in terms of shared category characteristics was formed. Consequently, an inevitable homogenisation and depersonalisation followed.

The cultural dynamics analysed in the context of Hindu-Muslim conflict in contemporary India shows that increasing numbers have begun to allude to religion as becoming their all-encompassing and exclusive identity that sets them apart from their neighbours who do not share in the same creed, hence creating sharp divisions between proximal ethnic groups. Driven by factors more akin to an ideological mindset, people have begun to mould their behaviour within the straitjacket of prespecified terms of reference, which are circulated at the collective level. Such overarching systems of partitioning have led to the creation of different ethnic identities where a singular trait, based on religion, foments the entire structure of the identity and hastily reduces the complexity of identity to a unidimensional phenomenon (Sen, A. 2006).

A new frame of reference grounded in an interactive historical past has to be created in order to resolve this complex issue. Academic discourse needs to accept that peacemaking in situations of interethnic conflict is highly dependent on social representations of historical conflict (Liu \& Hilton, 2005; Hilton \& Liu, 2008; Liu \& Atsumi, 2008). In the Indian context, the right-wing ideologues have subverted history and created their own charter which led to clear divisions in the polity. However, the same processes can be turned on their head. Referential points of anchoring derived from syncretic cultures and the use of collective symbolic coping (Wagner, Kronberger, \& Seifert, 2002) can help to overcome interethnic divide. Once identified, these referential points may help in promoting an integrative process that may lead to the formation of a syncretic plural society which is based on the strong foundation of a multilayered identity, where religion is considered a factor, amongst many others, on which identity pivots itself (Tripathi, 2005).

As our analysis shows, both Hindus and Muslims had gradually set aside the rich cultural heritage of syncretic religion and rode rough shod on little traditions during the BJP regime. Rustic homilies, exotic and integrated remixes, which served as a spiritual balm, were replaced by didactic religious tenets. Consequently, the lines of ethnic identity had become clearly demarcated, and syncretic culture did not seem to be attractive. It appeared to have lost its pull.

Sen and Wagner (2009) argue that this trend was in sharp contrast to earlier Indian culture, where often enough, the religious space of common people remained fluid and incorporated elements from the great traditions, whatever be their origin: Hindu, Muslim, Buddhist or tribal. This eclectic assimilation, which was free from the boundaries of religion, had helped people to come to terms with an often hostile environment within which they existed. The most outstanding example of such cultural intermingling was that which took place between Hindus and Muslims over 
an extended period and gave rise to syncretic popular cultures, which are not centrally organised and lack a formal canon. Both religions had integrated some aspects of the other within their own mainstream religiocultural matrices. As a result, syncretic cultures grew. Consequently, unusual gurus, "the dramatist of popular angst" (Banerjee, 2002), struck a chord in people's imagination. Banerjee's account of saint Satyapir or Satyanarayan who claimed that "I am Rahim in Mecca, in Ayodhya Ram " lucidly illustrates this dual religious identity. Two distinct religious identities (Hindu and Muslim) were merged and used interchangeably. Yet another testimony of this cultural intermingling was that all over India, posters were sold which together with the icons of Mecca and Medina depicted the portraits of saints and a pictorial version of the legends and miracles associated with them. Such syncretic cultures, we believe, will help strengthen the roots of a multicultural society by being effective in overcoming the power of institutionalised riot systems, blurring interethnic lines and increasing interconnections/contact. These may together help in evolving a reconciliation perspective which is a step towards resolving emotional issues that may have previously left ethnic groups estranged (Nadler \& Liviatan, 2004).

In the creation and maintaining of such syncretic cultures, it is the richness of multidimensional identity and the use of symbolic coping mechanisms which perhaps need to be focussed on and their importance cognised. A lesson for this can be learnt from Mohandas Karamchand Gandhi, who, in pre-independent India, through the use of symbols helped to bridge the schism between the Hindus and Muslims and managed to overcome the British policy of divide and rule (Sen \& Wagner, 2009). This approach if adopted may help replace the cacophony of discord with harmonious coexistence and be an important step towards the creation of peace in Asia.

\section{References}

Abric, J. C. (1996). Specific processes of social representations. Papers on Social Representations, $5,77-80$.

Adinarayan, S. P. (1941). A study in colour prejudice. British Journal of Psychology, 31, 217-229.

Adinarayan, S. P. (1953). Before and after independence; a study of racial and communal attitudes in India. British Journal of Psychology, 44, 108-115.

Adinarayan, S. P. (1964). The case for colour. Bombay, India: Asian Publishing House.

Akbar, M. J. (2003). Riot after riot: Reports on caste and communal violence in India. New Delhi: Roli Books.

Allport, G. W. (1954). The nature of prejudice. Oxford, England: Addison-Wesley.

Altemeyer, B. (1996). The authoritarian specter. Cambridge, MA, US: Harvard University Press.

Banerjee, S. (2002). Logic in a popular form: Essays on popular religion in Bengal. Calcutta: Seagull Books.

Bano, S., \& Mishra, R. C. (2005). Inter-group perception and evaluation among Hindu and Muslim children. Psychological Studies, 50, 144-149.

Basu, A. (1996). Mass movement or elite conspiracy? The puzzle of Hindu nationalism. In D. Ludden (Ed.), Making India Hindu. Delhi: Oxford University Press. 
Basu, J., Ahluwalia, N. K., \& Gangjee, K. (2006). Communal stereotype and family relationships within inter-religious marriage in India: Comparison with uni-religious families. Social Science International, 22, 66-80.

Basu, J., Hasan, R., Gangjee, K., Dasgupta, S., \& Dey, S. (2005). Development of a tool for assessing religious communal stereotype in India. Social Science International, 21, 55-67.

Basu, T., Datta, P., Sarkar, S., Sarkar, T., \& Sen, S. (1993). Khaki shorts saffron flags. New Delhi: Orient Longman.

Bhargava R. (2002). Liberal, secular democracy and explanations of Hindu nationalism. Oxford: Routledge.

Brass, P. (1991). Ethnicity and nationalism: Theory and comparison. Delhi: Sage.

Brass, P. R. (2003). The production of Hindu-Muslim violence in contemporary India. Seattle: University of Washington Press.

Braun, V., \& Clarke, V (2006). Using thematic analysis in psychology. Qualitative Research in Psychology, 3, 77-101.

Chopra, V.D. (1994). Religious fundamentalism in Asia.New Delhi: Gyan.

Christie, D. J. (2006). What is peace psychology the psychology of? Journal of Social Issues, 62, $1-17$.

Ellens, J. H. (2006). Fundamentalism, violence and war. In M. Fitzduff \& C. Stout (Eds.), The psychology of resolving global conflicts: From war to peace (Vol. 1). Westport, CT: Praeger Security International.

Embree, A. T. (Ed.). (1991). Sources of Indian tradition (Vol. 1). India: Penguin.

Engineer, A. A. (1995). Communalism in India: A historical and empirical study. New Delhi: Vikas Publishing House.

Enriquez, V. G. (1994). From colonial to liberation psychology: The Philippine experience. Manila: De La Salle University Press.

Esses, V. M., Jackson, L. M., \& Armstrong, T. L. (1998). Intergroup competition and attitudes toward immigrants and immigration: An instrumental model of group conflict. Journal of Social Issues. Special Issue: Understanding and Resolving National and International Group Conflict, 54, 699-724.

Gardner, M. (1953). In the minds of men the study of human behavior and social tensions in India. Oxford, England: Basic Books.

Gaur, S. D. (2004). Aggression amongst majority-minority communities in India. Psychological Studies, 49, 245-255.

Ghosh, E. S., \& Kumar, R. (1991). Hindu-Muslim intergroup relations in India: Applying sociopsychological perspectives. Psychology and Developing Societies, Special Issue: Conflict and Harmony in Pluralistic Societies, 3, 93-112.

Ghosh, E. S. K., Kumar, R., \& Tripathi, R. C. (1992). The communal cauldron: Relations between Hindus and Muslims in India and their reactions to norm violations. In R. deRidder \& R. Tripathi (Eds.), Norm violation and intergroup relations (pp. 70-89). New York, NY: Clarendon Press/Oxford University Press.

Golwalkar, M. S. (1939). We or our nationhood defined. Nagpur: Bharat Publications.

Gooptu, N. (2002). India and Partition. Retrieved June 17, 2008, from, http://www.sant.ox.ac.uk/ areastudies/lectures/gooptu.html

Hardy, P. (1972). The Muslims of British India. Cambridge: Cambridge University Press.

Hassan, M. K., \& Khalique, A. (1981). Religiosity and its correlates in college students. Journal of Psychological Researches, 25, 129-136.

Hewstone, M., \& Brown, R. (1986). Contact and conflict in intergroup encounters. Oxford, UK: Basil Blackwell.

Hilton, D. J., \& Liu, J. H. (2008). Culture and inter-group relations. The role of social representations of history. In R. Sorrentino \& S. Yamaguchi (Eds.), The handbook of motivation and cognition: The cultural context (pp. 343-368). New York: Guilford.

Hood, R. W., Hill, P. C., \& Williamson, W. P. (2005). The psychology of religious fundamentalism. New York, NY, US: Guilford Press. 
Hutnik, N. (2004). An intergroup perspective on ethnic minority identity. In J. Pandey (Ed.), Psychology in India revisited: Developments in the discipline, Vol. 3: Applied social and organisational psychology (pp. 216-260). Thousand Oaks, CA: Sage Publications.

Hwang, K. (2005). A philosophical reflection on the epistemology and methodology of indigenous psychologies. Asian Journal of Social Psychology.Special Issue: Responses to the Epistemological Challenges to Indigenous Psychologies, 8, 5-17.

Jaffrelot, C. (1996). The Hindu nationalist movement and Indian politics: 1925 to the 1990s: strategies of identity-building, implantation and mobilisation. London: Hurst.

Jalal, A. (1985). The sole spokesman: Jinnah, the Muslim league and the demand for Pakistan. Cambridge: Cambridge University Press.

Jefferey, P., \& Jefferey R. (2002). A population out of control? Myths about Muslim fertility in contemporary India. World Development, 30, 1805-1822.

Jhingran, S. (1995). Secularism in India.New Delhi: Manohar Publishers and Distributors.

Kakar, S. (1996). The colors of violence: Cultural identities, religion and conflict. Chicago: University of Chicago Press.

Kakar, S. (2000). The time of Kali: Violence between religious groups in India. Social Research, $67,877-899$.

Khan, S. S., \& Liu, J. H. (2008). Intergroup attributions and ethnocentrism in the Indian Subcontinent: The ultimate attribution error revisited. Journal of Cross Cultural Psychology, 39, 16-36.

Khan, S. S., Liu, J. H., \& Fischer, R. (2007, August). Hindutva: An intergroup perspective of social tensions among Hindus and Muslim in India. Paper presented at the 7th Biennial Conference of the Asian Association of Social Psychology (ASAP), Kota Kinabalu, Sabah, Malaysia.

Khan, S. S., Liu, J. H., \& Fischer, R. (2008, March). Hindutva: An Intergroup Perspective of Communal Tensions in India. Paper presented format at the Annual Conference of the Society for Australasian Social Psychology (SASP), Wellington, New Zealand.

Lakoff, G. (1987). Women, fire and dangerous things. Chicago, IL: University of Chicago Press.

Lal, V. (2003a, August 6). History sheeters. The Hindustan Times.

Lal, V. (2003b). The history of history: Politics and scholarship in modern India. New Delhi: Oxford University Press.

Leung, K. (2003). Asian peace psychology: What can it offer? Peace and Conflict: Journal of Peace Psychology, 9, 297-302.

Liu, J. H., \& Atsumi, T. (2008). Historical conflict and resolution between Japan and China: Developing and applying a narrative theory of history and identity. In T. Sugiman, K. J. Gergen, W. Wagner, \& Y. Yamada (Eds.), Meaning in action: Constructions, narratives, and representations (pp 327-344). Tokyo: Springer-Verlag.

Liu, J. H., \& Hilton, D. (2005). How the past weighs on the present: social representations of history and their role in identity politics. British Journal of Social Psychology, 44,1-21

Ludden, D. E. (Ed.). (2005). Making India Hindu: Religion, community, and the politics of democracy in India. Delhi: Oxford University Press.

Mackie, D. M., \& Smith, E. R. (Eds.). (2002). From prejudice to intergroup emotions: Differentiated reactions to social groups. Philadelphia: Psychology Press.

Mamali, C. (2006). The value of images for exploring the functions of social representations: toward self-generated pictorial social representations. A Comment on "History, emotions and hetero-referential representations" by Sen and Wagner (2005). Papers on Social Representations, 15, 3.1-3.9. Retrieved December 11, 2006, from http://www.psr.jku.at/

McGuire, J., Reeves, P., \& Brasted, H. (Eds.). (1996). Politics of violence: From Ayodhya to Behrampada. Delhi: Sage.

Middleton, D., \& Edwards, D. (1990). Collective remembering. Thousand Oaks, CA, US: Sage Publications, Inc.

Mishra, S. (2005). Religious identity and ego strengths: A study of Hindu and Muslim boys and girls. Psychological Studies, 50, 127-133.

Moeschberger, S. L., Dixon, D. N., Niens, U., \& Cairns, E. (2005). Forgiveness in northern ireland: A model for peace in the midst of the "troubles". Peace and Conflict: Journal of Peace Psychology, 11, 199-214. 
Montiel, C. J. (2003). Peace psychology in Asia. Peace and Conflict: Journal of Peace Psychology, 9, 195-218.

Moscovici, S. (1976). La psychanalyse son image et son public. Paris: Presses Universitaires de France.

Murphy, G. (1953). In the minds of men the study of human behaviour and social tensions in India. Oxford, England: Basic Books.

Nandy, A. (1990). The politics of secularism and the recovery of religious tolerance. In V. Das (Ed.), Mirrors of violence. Delhi: Oxford University Press.

Nadler, A., \& Liviatan, I. (2004). Intergroup reconciliation processes in Israel: Theoretical analysis and empirical fi ndings. In N. R. Branscombe, \& B. Doosje (Eds.), Collective guilt: International perspectives (pp. 216-235). Cambridge: Cambridge University Press.

Nandy, A., Trivedi, S., Mayaram, S., \& Yagnik, A. (1995). Creating a nationality: The Ramjanmabhumi movement and the fear of self. Delhi: Oxford University Press.

Pandey, G. (1991). In defence of the fragment: Writing about Hindu-Muslim riots in India today, Economic and Political Weekly, Annual Number, March 1991.

Pandey, G. (2001). Remembering partition: Violence, nationalism and history in India. Cambridge: Cambridge University Press.

Pandey, J., \& Singh, P. (2005). Social psychology in India: Social roots and development. International Journal of Psychology. Special Issue: Social Psychology Around the World: Origins and Subsequent Development, 40, 239-253.

Panikkar, K. M. (1927). The psychology of the Hindu-Muslim riots. Contemporary Review, 131, 230-236.

Pennebaker, J. W., Paez, D., \& Rimé, B. (1997). Collective memory of political events. Mahwah, NJ: Lawrence Erlbaum.

Pettigrew, T. F. (1979). The ultimate attribution error: Extending Allport's cognitive analysis of prejudice. Personality and Social Psychology Bulletin, 5, 461-476.

Pettigrew, T. F. (1986). The contact hypothesis revisited. In M. Hewstone \& R. Brown (Eds.), Contact and conflict in intergroup encounters. (pp. 169-195). Oxford, England: Basol Blackwell.

Philpot, C. R., \& Hornsey, M. J. (2008). What happens when groups say sorry: The effect of intergroup apologies on their recipients. Personality and Social Psychology Bulletin, 34, 474-487.

Pratto, F, Sidianus, J., Stallworth, L. M., \& Malle B. F. (1994). Social dominance orientation: A personality variable predicting social and political attitudes. Journal of Personality and Social Psychology, 67, 741-76

Punyani, R. (2003). Communal politics: Facts versus myths. New Delhi: Sage

Ramakrishnan, V. (2006, January 14-27). A legacy of duplicity. Frontline, 23, 01.

Reicher, S., \& Hopkins, N. (2001). Self and nation. London: Sage.

Savarkar, V. D. (1923). Hindutva. Bombay: Savarkar Prakashan.

Sen, A. (2006). Identity and violence:The illusion of destiny. New York, NY: W. W. Norton \& Co.

Sen, R. (2005). Us vs. them and Gandhi: The case of Hindu-Muslim conflict in India. Psychological Studies, 50, 111-116.

Sen, R., \& Wagner, W. (2005). History, emotions and hetero-referential representations in intergroup conflict: The example of Hindu-Muslim relations in India. Papers on Social Representations, 16, 2.1-2.23.

Sen, R., \& Wagner, W. (2009). Central mechanics of fundamentalism: Religion as ideology, divided identities and violence in post Gandhi India. Culture and Psychology, 15 (3).

Shah, T. S. (2004). Muslims in Hindu nationalist India: A conversation with Asghar Ali Engineer and Paul R. Brass. Center Conversations, 28, 1-9.

Shankar, J., \& Gerstein, L. H. (2007). The Hindu-Muslim conflict: A pilot study of peacebuilding in Gujarat, India. Peace and Conflict: Journal of Peace Psychology, 13, 365-379.

Singh, A. K. (1989). Intergroup relations and social tensions. In J. Pandey (Ed.), Psychology in India: The state-of-the-art, Vol. 2: Basic and applied social psychology (pp. 159-223). Thousand Oaks, CA: Sage Publications. 
Sinha, D. (1998). Changing perspectives in social psychology in India: A journey towards indigenization. Asian Journal of Social Psychology, 1, 17-31.

Smith, A. D. (1998). Nationalism and modernism: A critical survey of recent theories of nations and nationalism. New York: Routledge.

Stephan, W. G., \& Stephan, C. W. (2000). An integrated threat theory of prejudice. Mahwah, NJ, US: Lawrence Erlbaum Associates Publishers.

Tam, T., Hewstone, M., Cairns, E., Tausch, N., Maio, G., \& Kenworthy, J. (2007). The impact of intergroup emotions on forgiveness in northern ireland. Group Processes \& Intergroup Relations, 10, 119-136.

Tam, T., Hewstone, M., Kenworthy, J. B., Cairns, E., Marinetti, C., Geddes, L., et al. (2008). Postconflict reconciliation: Intergroup forgiveness and implicit biases in Northern Ireland. Journal of Social Issues, 64, 303-320.

Tausch, N., Hewstone, M., \& Roy, R. (2009). The relationship between contact, status, and prejudice: an integrated threat theory analysis of Hindu-Muslim relations in India. Journal of Community and Applied Social Psychology, 19 (2), 83-94.

Taylor, D. M., \& Jaggi, V. (1974). Ethnocentrism and causal attribution in a south Indian context. Journal of Cross-Cultural Psychology, 5, 162-171.

Tripathi, R. C. (2005). Hindu social identities and imagined past: The faceoff between Ram temple and martyred mosque at Ayodhya. Psychological Studies, 50, 102-110.

Tripathi, R. C., \& Srivastava, R. (1981). Relative deprivation and intergroup attitudes. European Journal of Social Psychology, 11, 313-318.

Valsiner, J. (2001). The first six years: Culture's adventures in Psychology. Culture Psychology, 7, $5-48$.

Varshney, A. (2002). Ethnic conflict and civic life: Hindus and Muslims in India. New Haven: Yale University Press.

Vollhardt, J. K., \& Bilali, R. (2008). Social psychology's contribution to the psychological study of peace: A review. Social Psychology.Special Issue: Social Psychology and Peace, 39, 12-25.

Wagner, W., Kronberger, N., \& Seifert, F. (2002). Collective symbolic coping with new technology: Knowledge, images and public discourse. British Journal of Social Psychology, 41, 323-343.

Wertsch, J. V. (2002). Voices of collective remembering. Cambridge: Cambridge University Press. Wilkinson, S. I. (2004). Votes and violence. Cambridge: Cambridge University Press.

Zakaria, R. (2002). Communal rage in secular India. Mumbai: Popular Prakashan. 